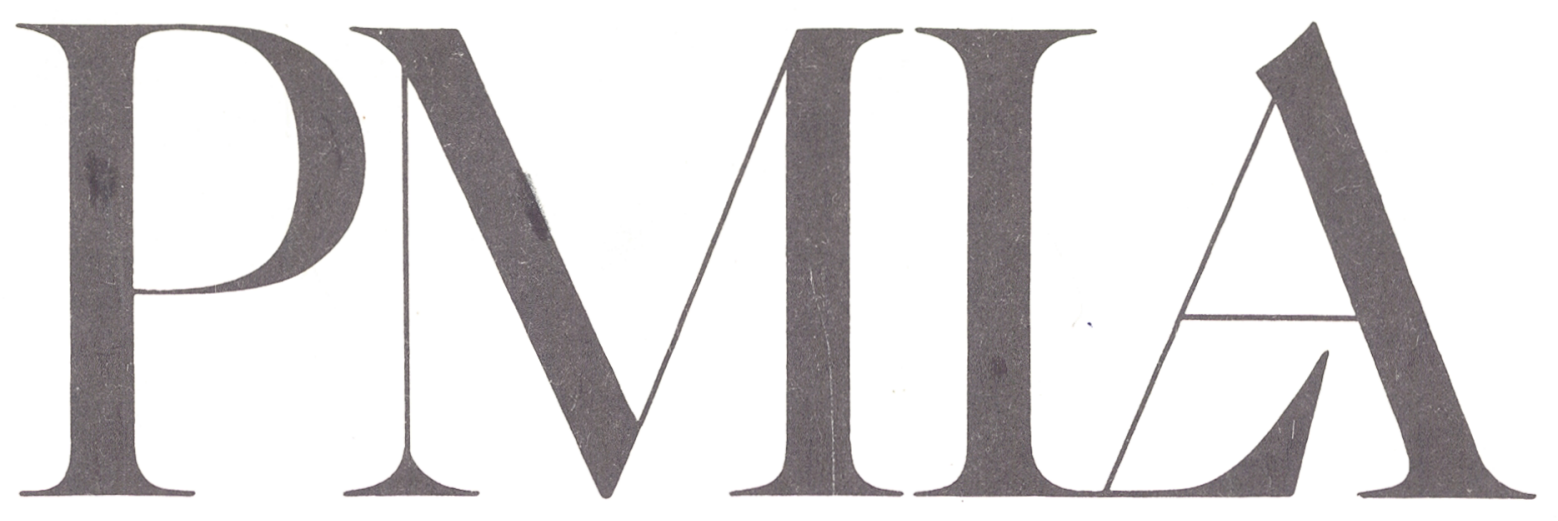

Publications of the

Modern Language Association

of America

November 1977

Volume 92 Number 6

Program 


\section{New from Illinois this year...}

\section{ILLINOIS SHORT FICTION}

The third set of collections;

simultaneous publication in cloth at $\$ 7.50$ each and in paper at $\$ 3.45$ each.

ONE MORE RIVER

Lester Goldberg

THE TENINIS PLAYER

Kent Nelson

A HORSE OF ANOTHER COLOR

Carolyn Osborn

THE PLEASURES OF MANHOOD

Robley Wilson, Jr.

POETRY AND

POETRY CRITICISM

\section{IMAGES OF KIN}

Michael S. Harper

Cloth, \$8.95; paper, \$3.95

\section{POEMS OF THE}

TWO WORLDS

Frederick Morgan

Cloth, \$7.95; paper, $\$ 3.95$

\section{UNASSIGNED FREQUENCIES}

American Poetry in Review, 1964-77

Laurence Lieberman $\$ 12.00$
BIOGRAPHY, BIBLIOGRAPHY, CRITICISM, HISTORY

ZORA NEALE HURSTON

A Literary Biography

Robert E. Hemenway $\$ 15.00$

\section{DOROTHY RICHARDSON}

A Biography

Gloria G. Fromm $\$ 15.00$

HENRY SALT

Humanitarian Reformer and Man of Letters

George Hendrick $\$ 10.00$

REMEMBRANCES OF CONCORD AND THE THOREAUS

Letters of Horace Hosmer to Dr. S. A. Jones

edited by George Hendrick $\$ 10.00$

\section{THE LIFE OF FICTION}

Jerome Klinkowitz. Graphics by

Roy R.Behrens $\$ 10.00$

THE FEDERAL WRITERS' PROJECT

A Study in Government Patronage of the Arts

Monty N. Penkower $\$ 10.00$

W. B. YEATS: A CLASSIFIED BIBLIOGRAPHY OF CRITICISM

Including Additions to Allan Wade's Bibliography of the Writings of W. B. Yeats and a Section on the Irish Literary and Dramatic Revival

compiled by K. P. S. Jochum $\$ 35.00$

\section{UNIVERSITY OF ILLINOIS PRESS}

Urbana, Illinois 61801 


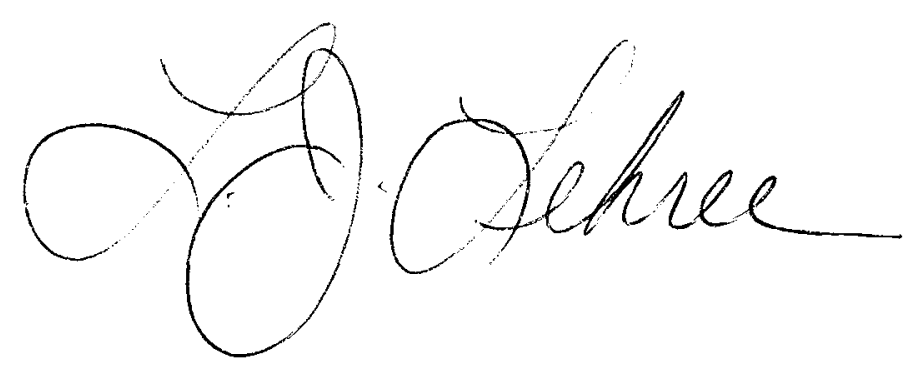

November 1977

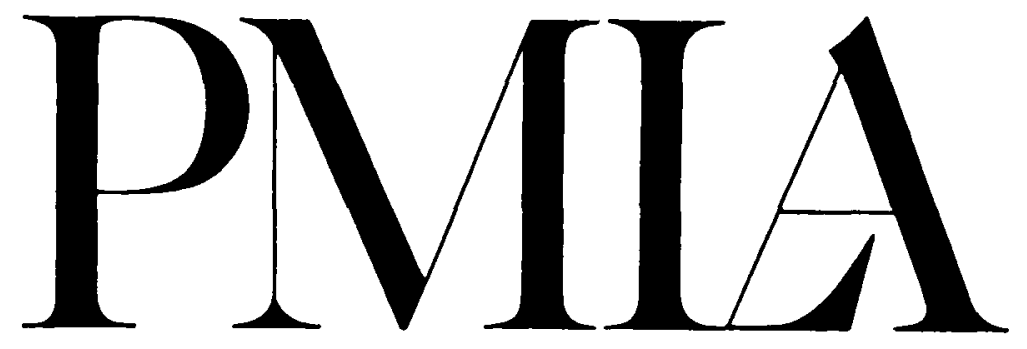

Publications of the

Modern Language Association of America

Program of the

92nd Annual Convention

Volume 92

Number 6

PUBLISHED SIX TIMES A YEAR BY THE ASSOCIATION 


\section{The Modern Language Association of America}

ORGANIZED 1883

INCORPORATED 1900

OFFICERS FOR THE YEAR 1977

President: EDITH KeRN, Hofstra University

First Vice-President: WALTER J. ONG, St. Louis University

Second Vice-President: Jean A. Perkins, Swarthmore College

Executive Director: William D. SCHAEFER

Deputy Executive Director: HaNs RüTIMANN

\section{EXECUTIVE COUNCIL}

For the term ending 31 December 1977

Mary Ann Caws

Hunter College, City University of New York

Stanley B. Greenfield

University of Oregon

THEODORE J. ZIOLKOWSKI

Princeton University

For the term ending 31 December 1979

David J. DeLaura

University of Pennsylvania

Carolyn G. Heilbrun

Columbia University

Ronald Paulson

Yale University
For the term ending 31 December 1978

Sidonie CASSIRER

Mount Holyoke College

Ruth S. El SAFFar

University of Illinois, Chicago Circle

EDWARD WaSIOLEK

University of Chicago

For the term ending 31 December 1980

GeOFFrey H. HARTMAN

Yale University

Winfred P. LEHMANN

University of Texas, Austin

Marilyn L. Williamson

Wayne State University

\section{TRUSTEES OF INVESTED FUNDS}

GORDON N. RAY

Guggenheim Foundation, Managing Trustee
C. WALlER BARRETt

Charlottesville, Virginia

ROBERT LUMIANSKY

American Council of Learned Societies

$P M L A$ is issued six times a year, in January, March, May, September, October, and November, by the Modern Language Association of America, 62 Fifth Avenue, New York, New York 10011. Membership is open to those persons who are professionally interested in the modern languages and literatures. Annual dues, which include subscription to $P M L A$, are based on members' salaries and are graduated as follows: student members, $\$ 10$; unemployed regular members, $\$ 10$; regular members (first 2 years), $\$ 20$; regular members (salary under $\$ 12,000$ ), $\$ 25$; regular members (salary $\$ 12,000-\$ 18,000$ ), $\$ 30$; regular members (salary over $\$ 18,000$ ), $\$ 35$; joint members (with only one subscription to $P M L A$ ), $\$ 45$; foreign members, same as regular members.

The subscription price of $P M L A$ for libraries and other institutions is $\$ 30$. A subscription including a bound volume at the end of the year is $\$ 45$, domestic and foreign. Agents deduct $10 \%$ as their fee. Single copies of the January, March, May, and October issues may be obtained for $\$ 5$ each; the November Program issue for $\$ 10$; the September Directory issue for $\$ 15$.

Issues for the current year are available from the MLA Publications Center. Claims for undelivered issues will be honored if they are received within one year of the publication date; thereafter the single issue price will be charged.

For information about the availability of back issues, inquire of Kraus Reprint Co., Millwood, N.Y. 10546; (914) 762-2200. Early and current volumes may be obtained on microfilm from University Microfilms, Ann Arbor, Mich. 48106. Purchase of current volumes on film is restricted to subscribers of the journal.

\section{OFFICE OF PUBLICATION AND EDITORIAL OFFICES \\ 62 Fifth Avenue, New York, N.Y. 10011 Tel.: 212 741-5588}

All communications, including notices of changes of address, should be sent to the Membership Office of the Association at 62 Fifth Avenue, New York, N. Y. 10011. If a change of address also involves a change of institutional affiliation, the Membership Office should be informed of this fact at the same time.

Second-class postage paid at New York, N.Y. and at additional mailing office.

Copyright (C) 1977 by The Modern Language Association of America.

Library of Congress Catalog Card Number 12-32040. 


\title{
PROGRAM OF THE NINETY-SECOND ANNUAL CONVENTION OF THE
}

\section{MODERN LANGUAGE ASSOCIATION \\ OF AMERICA}

\section{Chicago, Illinois}

27-30 December 1977

\begin{abstract}
About the MLA Convention . . . . . . . . 1060
Location of Meeting Rooms . . . . . . . . . . 1066

Program Summary . . . . . . . . . . . . . 1067

Indexes
\end{abstract}

Forums and Special Events . . . . . . . . 1080

Division Meetings . . . . . . . . . . . . 1081

Discussion Group and Section Meetings . . . . . 1082

Associated Meetings . . . . . . . . . . . 1083

MLA Meetings . . . . . . . . . . . . 1085

Subject Index to All Meetings . . . . . . . . 1086

Program

Tuesday, 27 December . . . . . . . . . . . 1098

Wednesday, 28 December . . . . . . . . . . 1109

Thursday, 29 December . . . . . . . . . 1142

Friday, 30 December . . . . . . . . . . . 1179

Program Participants . . . . . . . . . . . . 1189

Floor Plans and Maps . . . . . . . . . . . 1199

Exhibitors . . . . . . . . . . . . . . 1203

Map of Exhibit Area . . . . . . . . . . . 1205

Executive Committees

Division Executive Committees . . . . . . . . 1207

Discussion Group Executive Committees . . . . . 1213

Directory of Allied Organizations . . . . . . . . 1215 